\title{
PARAMETERS INVESTIGATION FOR INDEPENDENT PENDULAR SUSPENSION OF SPRAYER BOOM
}

\author{
Andrii Babii
}

\author{
Ternopil Ivan Puluj National Technical University, Ternopil, Ukraine
}

\begin{abstract}
Summary. New construction of the boom suspension designed in the form of four-link «batwing»-type lever is proposed in this paper. Its peculiarity is that it is constructed of two independent double-arm pendulums, oscillations of which are restricted by articulated elastic-damping elements. The kinematic relationship between deformation of elastic suspension element and the sprayer boom motion is determined. The dynamic model describing this oscillation process is developed in order to test the ability of the given independent suspension to damp boom vibrations. The solutions for the partial case of boom oscillations occurence are obtained, due to their analysis the efficiency of the proposed suspension can be estimated.
\end{abstract}

Key words: sprayer boom, amplitude, static motion, suspension, pendulum, deformation, fluctuation, boom stabilization.

Statement of the problem. Agricultural sprayer booms of wide allotment still remain the main machines providing technological operation of chemical protection in crop production. Technical and technological requirements are increasing for this class of machines [1]. One of the main criteria for the sprayer high performance is the qualitative application of the working agent on the plants, where the stabilization of the boom vibrations is of great importance.

Deviation of the optimum height of the working agent spray over the treated surface by $10 \mathrm{~cm}$ height changes the flow rate of the working solution in the overlap area $+40 \%$ or in other zones $-30 \%$ from the specified norm. At low application rates, such inappropriate boom mounting height can cause the fine particles blowing by the wind and then the rate can be reduced, even by half $[2,3]$.

Besides, the occurring oscillations of the suspension boom caused by field irregularities during the sprayer motion, result in increased dynamic loads on the suspension elements of the boom and its frames. The combination of this mechanical load and the influence of the aggressive environment of pesticides or liquid fertilizers on the sprayer metal structures significantly reduces their operational life $[1,4,5]$.

Therefore, the development of effective structures of sprayer suspension booms providing their maximum stabilization is very important.

Analysis of the available investigations and publications. Analyzing the literature sources, the authors identify many types of mechanical suspensions (without the use of additional service devices). The basic principal suspension schemes include: copying, simple with different damping mechanisms, pendulums: single-hinge, single-hinge with independent wing sections adjustment with balancing lever, universal double-hinged, double-hinged or fourhinged of A-type, double-hinged or four-hinged of V-type, four-hinged of "batwing"-type etc. [6]. Besides, lever parallelogram suspensions of sprayer booms are becoming more and more popular today. Certainly, manufacturers of agricultural sprayers are aimed at reducing the manufactured products cost, and, on the contrary, by increasing its technological efficiency to increase the competitiveness of such machines on the market. Therefore, production requires 
from the scientists and designers to solve the problem of improving the stabilization properties of simpler suspension structures as much as possible.

There are many patent designs of sprayer boom suspensions of both domestic and foreign researchers. Among the Ukrainian scientists, the theoretical foundations of the suspension operation and sprayer booms oscillations are trashed out in papers by I. A. Vikovych, B. M. Diveieva, M. F. Dmytrychenko, and I. R. Dorosh. [6-8]. But there is the need for theoretical investigation of the newly developed suspension, which should meet the requirements for the boom stabilization level.

The objective of the paper is to substantiate theoretically the ability to stabilize the designed suspension structure of the sprayer boom on the example of partial case of oscillations occurrence.

Statement of basic materials. A new sprayer boom suspension design, which refers to four-linked «batwing»-type lever suspension is proposed. The symmetrical half of the given suspension construction is shown in Figure 1. Its peculiarity is that it is made by two independent double-armed pendulums, the oscillations of which are restricted by the hinged elastic-damping elements 3. Compared with the similar structures of such suspensions, for example [9], it is independent, eliminating the effect of elastic-damping deformation of the pendulum element on the other one, and the use of the damper makes it possible to damp the resulting oscillations quickly.

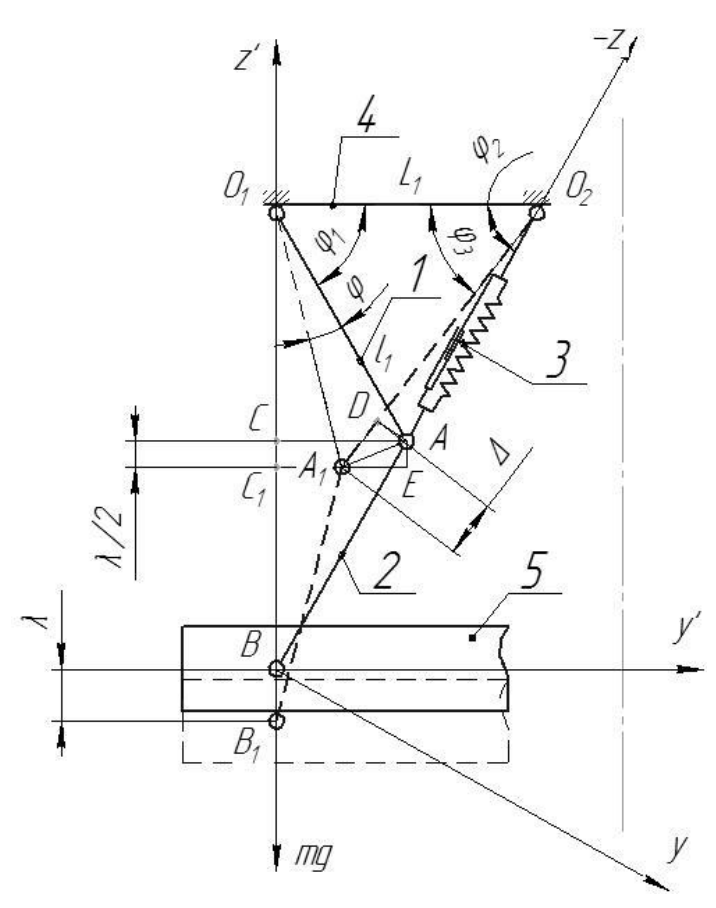

Figure 1. The calculation scheme of the sprayer boom suspension
Let us consider the partial case of sprayer suspension boom oscillations when only vertical oscillations occur during the sprayer motion along field irregularities. This approach is used in order to investigate the independent suspension parameters concerning the ability to damp the resulting boom vibrations. Let's divide the problem into several simpler ones.

In the first stage of the investigation it is necessary to determine the structuralkinematic relationship between the boom suspension $\lambda$ movement and the actual deformation of the elastic-damping element of pendulum $\Delta$, Figure 1. Let us assume that the pendulum links have the same length $l_{1}$ (the condition is optional, the links lengths can be different), so if we consider the vertical displacement point $\mathrm{A}$ of the link 1 , it will be $\lambda / 2$ from boom $\lambda$ movement, the same will be for point B in link 2 . The sum of points $A$ and $B$ vertical displacements will be $\lambda$.

Thus, taking into account the setting angle $\varphi_{1}$ and the length of link $1 l_{1}$, as well as in accordance with Figure 1, we get

$$
\begin{gathered}
\frac{\lambda}{2}=O_{1} C_{1}-O_{1} C \text { or } \\
\frac{\lambda(\varphi)}{2}=l_{1} \cdot\left(\sin \left(\varphi_{1}+\varphi\right)-\sin \varphi_{1}\right),
\end{gathered}
$$


where $\varphi$ is the angular coordinate determining the position of the pendulum link 1 relatively to the equilibrium position.

On the other hand, in the static equilibrium position, the system of links 1, 3, 4 form triangle $\mathrm{O}_{1} \mathrm{AO}_{2}$ which parameters are known. Under the boom weight force action on the pendulum links 2 and 1, this force is transmitted to the elastic-damping element (link 3), which deforms. Accordingly, link 1 is rotated through angle $\varphi$ and new triangle $O_{1} A_{1} O_{2}$ is formed. Moreover, only link 3 length changes $O_{2} A_{1}$ or we denote it by $R(\varphi)$ characterizing deformation $\Delta(\varphi)$ of elastic-damping element.

Then, if the setting length of the elastic-damping element is $R_{0}$, then its deformation is

$$
\Delta(\varphi)=R(\varphi)-R_{0}
$$

In expanded form we get

$$
\Delta(\varphi)=\sqrt{L_{1}^{2}+l_{1}^{2}-2 L_{1} l_{1} \cos \left(\varphi_{1}+\varphi\right)}-R_{0}
$$

where $L_{1}$ is designed distance of the boom suspension hinges fixing.

Here it is necessary to determine the relationship between the boom $\lambda$ displacement and deformation of the pendulum elastic damping element $\Delta(\varphi)$.

Let us consider triangles $A_{1} D A$ and $A_{1} E A$ with common side $A_{1} A$. Triangle $A_{1} E A$ is right-angled, and $E A=\lambda / 2$. Then

$$
A_{1} A=\sqrt{A E^{2}+A_{1} E^{2}},
$$

here $A_{1} E=l_{1} \cdot\left(\cos \varphi_{1}-\cos \left(\varphi_{1}+\varphi\right)\right)$.

From triangle $A_{1} D A$ :

$$
A_{1} A=\sqrt{\Delta(\varphi)^{2}+D A^{2}-\Delta(\varphi) \cdot D A \cos \alpha},
$$

where $\quad D A=\sqrt{2 R_{0}^{2}\left(1-\cos \left(\varphi_{2}-\varphi_{3}\right)\right)}, \quad$ and $\quad$ angle $\quad \varphi_{3}=\arccos \frac{R(\varphi)^{2}+L_{1}^{2}-l_{1}^{2}}{2 R(\varphi) L_{1}}$ $\angle A_{1} D A=\alpha=90^{\circ}+\frac{\varphi_{2}-\varphi_{3}}{2}$.

Then it will be valid to equate the obtained dependences (3) and (4), squaring the left and right parts of the equality, we get

$$
\begin{gathered}
(\lambda / 2)^{2}+\left(l_{1} \cdot\left(\cos \varphi_{1}-\cos \left(\varphi_{1}+\varphi\right)\right)\right)^{2}= \\
=\Delta(\varphi)^{2}+2 R_{0}^{2}\left(1-\cos \left(\varphi_{2}-\varphi_{3}\right)-\Delta(\varphi) \cdot \sqrt{2 R_{0}^{2}\left(1-\cos \left(\varphi_{2}-\varphi_{3}\right)\right)} \cdot \cos \alpha\right.
\end{gathered}
$$

where the displacement of the suspension boom is 


$$
\lambda=2 \sqrt{\begin{array}{l}
\Delta(\varphi)^{2}+2 R_{0}^{2}\left(1-\cos \left(\varphi_{2}-\varphi_{3}\right)-2 \Delta(\varphi) R_{0} \sqrt{2\left(1-\cos \left(\varphi_{2}-\varphi_{3}\right)\right)} \cdot \cos \alpha-\right. \\
-\left(l_{1} \cdot\left(\cos \varphi_{1}-\cos \left(\varphi_{1}+\varphi\right)\right)\right)^{2}
\end{array}}
$$

For visual comparison of deformation values of the pendulum elastic-damping element $\Delta(\varphi)$ and actual boom displacement $\lambda$, let us assume: $O_{1} A=B A=l_{1}=0,5 \mathrm{~m}$; $O_{1} O_{2}=L_{1}=0,494 \mathrm{~m} ; A O_{2}=R_{0}=0,5 \mathrm{~m} ; \varphi_{1}=\varphi_{2}=60,4^{0} ;$ the boundaries of angle change $\varphi=0 \ldots\left(90^{\circ}-\varphi_{1}\right)$. In Figure 1 shows: by the line formed by dots - deformation of the pendulum elastic-damping element; solid line - the actual suspension boom movement $\lambda(\varphi)$.

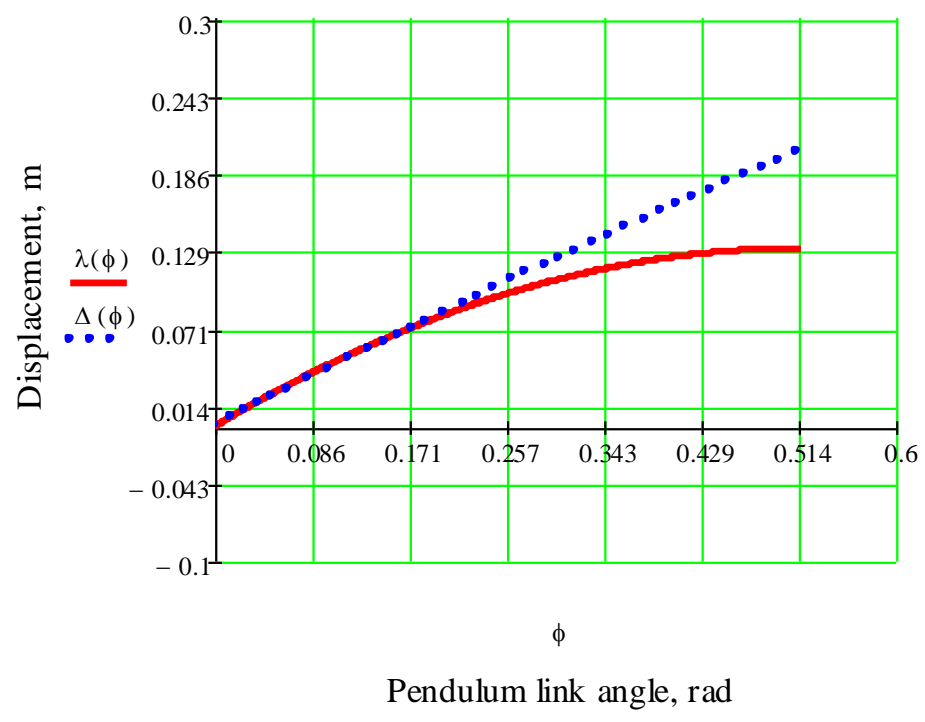

Figure 2. Graphical dependencies of vertical displacement of the boom $\lambda(\varphi)$ and deformation of the pendulum elastic-damping element $\Delta(\varphi)$

Here we can make the conclusion that the use of double-armed pendulum suspension makes it possible to provide greater movement (deformation) for elastic-damping element compared to the actual movement of the suspension boom. For the accepted designed suspension dimensions, the maximum difference of the received displacements is up to $36 \%$. The obtained effect should be used as one of the factors for stabilizing the suspension boom of the wide-coverage sprayer.

Let us move on to the second stage of the investigation - the ability to damp the vertical oscillations of the suspension boom developed by the suspension.

Let us consider the operation of elastic-damping element as the mechanical system having one freedom degree and moves along axis $z$, drawn along the axis of this element. The result of the occurring oscillations investigation is the law of reduced mass motion, characterizing the law of the pendulum elastically-damping element deformation change $\Delta(\varphi)$, thereon, using dependence (5), and the displacement of the suspension boom $\lambda$.

Taking into account the designed structure of the boom suspension, it is possible to consider any of its symmetrical halves. In addition, the gravity force transmitted to the pendulum elastic-damping element through its links, is

$$
G=m g \cdot \sin \left(\varphi_{1}+\varphi\right) \cdot \cos \left(\varphi_{1}+\varphi-\varphi_{3}\right)
$$


where $m$ is the weight of the half of sprayer suspension boom, $\mathrm{kg}$; $g$ is gravitational acceleration, $g=9,81 \mathrm{~m} / \mathrm{s}^{2}$.

Having accepted the modular value of the gravity force $m g$ as $100 \%$, and according to the analysis of the obtained dependence (6) with the given designed parameters of the suspension, the given gravity force of the boom from value $m g:$ is $87 \%$ at the beginning of movement (deformation) of the pendulum elastic-damping element; the maximum value is $91 \%$ (at $\left.\varphi=9,1^{0}\right) ; 71 \%-$ at $\varphi_{\max }$.

The maximum load spread from the highest value $(0,91 \mathrm{mg})$ is $22 \%$, which is quite significant, and at the end of the pendulum suspension movement this value is minimal. But taking into account the fact that the value of the gravity force in the suspension oscillations operating range (maximum amplitude $0.1 \mathrm{~m}$ ) is not more than $5 \%$, then in order to avoid the cumbersome theoretical arguments, we assume that the gravity force is constant while acting on the pendulum elastically-damping element. But for more adequate estimation of the oscillatory process, the parameters calculation is carried out according to three given characteristic values (depending on the pendulum links position) of the boom gravity forces weight.

For preliminary verification of the operating ability of the pendulum independent suspension of the sprayer boom, we use simplified dynamic model containing restoring force $F_{z}$, dissipative force $R_{z}$ and coercive force $P_{z}$ [10].

The gravity force, which is given to point A of the pendulum elastic-damping element and causes its static deformation, is given in the following form

$$
G=c \Delta_{0}
$$

where $c$ is elastic element rigidity;

$\Delta_{0}$ is static deformation of the elastic element.

In the general case, the restoring force is as follows

$$
F_{z}=-c\left(\Delta_{0}+\mathrm{z}\right)
$$

here $\mathrm{z}$ is displacement of mass concentrated in point $\mathrm{A}$.

Dissipative force is

$$
R_{z}=-\mu \cdot \dot{z}
$$

where $\mu$ is the coefficient of damper viscous resistance;

$\dot{z}$ is the damper stem movement speed.

As the coercive force, we assume the harmonic law that adequately describe the force impulses transmitted to the considered oscillating mass when the sprayer is moves along field irregularities.

$$
P_{z}=H_{0} \sin (\omega t+\beta)
$$

where $H_{0}$ is the coercive force amplitude;

$\omega$ is of coercive force frequency;

$\beta$ is phase shift. 
Based on the acting forces, it is possible to write the differential equation of reduced mass motion to point $\mathrm{A}[10]$

$$
\frac{G}{g} \ddot{z}=G-c\left(\Delta_{0}+\mathrm{z}\right)-\mu \dot{z}+H_{0} \sin (\omega t+\beta)
$$

To bring equation (11) to the standard form, we make a number of substitutions:

$$
2 h=\frac{\mu g}{G}, k^{2}=\frac{c g}{G}, H=\frac{H_{0} g}{G} .
$$

Let us rewrite equation (11) in the following form

$$
\ddot{z}+2 h \dot{z}+k^{2} z=H \sin (\omega t+\beta)
$$

and we get linear non-uniform differential equation, which we integrate using well-known approaches.

The solution of equation (13) is the sum of the homogeneous equation solutions derived from (13) and the partial solution of inhomogeneous equation, i. e.

$$
z=z_{1}+z_{2}
$$

Therefore, the homogeneous equation has the following form $[8,10]$

$$
\ddot{z}+2 h \dot{z}+k^{2} z=0
$$

we write down its solution for the case $k>h$. By omitting the intermediate calculations of the standard solution procedure in this case, we write the final result

$$
z_{1}=e^{-h t}\left(C_{1} \cos p t+C_{2} \sin p t\right)
$$

where $C_{1}, C_{2}$ are integration constants determined from the initial conditions;

$$
p=\sqrt{k^{2}-h^{2}} .
$$

We construct the partial solution of equation (13) using the uncertain coefficients method [10]

$$
z_{2}=M \sin (\omega t+\beta)+N \cos (\omega t+\beta)
$$

Further, it is necessary to substitute (17) and its corresponding derivatives into (13) and select the coefficients $M, N$ in such a way that the equality condition (13) is satisfied. For this purpose, after simple transformations we get the system of linear algebraic equations in the form: 


$$
\left.\begin{array}{l}
\left(k^{2}-\omega^{2}\right) M-2 \omega h N=H ; \\
2 \omega h M+\left(k^{2}-\omega^{2}\right) N=0 .
\end{array}\right\}
$$

The solution of this system are the obtained coefficients:

$$
M=\frac{H\left(k^{2}-\omega^{2}\right)}{\left(k^{2}-\omega^{2}\right)^{2}+4 \omega^{2} h^{2}}, \quad N=-\frac{2 \omega h H}{\left(k^{2}-\omega^{2}\right)^{2}+4 \omega^{2} h^{2}} .
$$

Let us rewrite the values of the obtained coefficients in more compact form:

$$
M=a \cos \varepsilon, \quad N=-a \sin \varepsilon,
$$

where $\operatorname{tg} \varepsilon=-\frac{N}{M}=\frac{2 \omega h}{k^{2}-\omega^{2}} ; a=\sqrt{M^{2}+N^{2}}=\frac{H}{\sqrt{\left(k^{2}-\omega^{2}\right)^{2}+4 \omega^{2} h^{2}}}$.

Let us represent solution (17) as follows

$$
z_{2}=a \sin (\omega t+\beta-\varepsilon)
$$

Now you can eventually rewrite (14), which is the general solution of equation (13)

$$
z=e^{-h t}\left(C_{1} \cos p t+C_{2} \sin p t\right)+a \sin (\omega t+\beta-\varepsilon) .
$$

When the solution of the equation is constructed, the final stage is to find integration constants determining the nature of the entire boom suspension oscillating process.

Let us write the initial conditions for integration constants finding:

$$
t_{0}=0,(z)_{t=t_{0}}=z_{0},(\dot{z})_{t=t_{0}}=\dot{z}_{0} .
$$

Substituting $t_{0}=0$ in (22), we get

$$
z_{0}=C_{1}+a \sin (\beta-\varepsilon)
$$

In order to determine $\dot{z}_{0}$, it is necessary to find the first derivative from (22), that is

$$
\dot{z}=e^{-h t}\left\{C_{1}[-h \cos p t-p \sin p t]+C_{2}[-h \sin p t+p \cos p t]\right\}+a \omega \cos (\omega t+\beta-\varepsilon),
$$

then at $t_{0}=0$, we get

$$
\dot{z}_{0}=-h C_{1}+C_{2} p+a \omega \cos (\beta-\varepsilon) .
$$

Solving simultaneously (24) and (26), we get the values of integration constants: 


$$
\begin{gathered}
C_{1}=z_{0}-a \sin (\beta-\varepsilon) \\
C_{2}=\frac{\dot{z}_{0}+h z_{0}}{p}-\frac{a[h \sin (\beta-\varepsilon)+\omega \cos (\beta-\varepsilon)]}{p} .
\end{gathered}
$$

Thus, in this calculation model all components are described. Let's move on to practical investigation.

To test the ability to damp the oscillation of suspension boom developed by lever independent suspension design we accept: $c=3,8 \cdot 10^{4} \frac{\mathrm{N}}{\mathrm{m}} ; \mu=1,5 \cdot 10^{3} \frac{\mathrm{N} \cdot \mathrm{s}}{\mathrm{m}} ; \omega=1,5 \mathrm{~Hz}$; $H_{0}=100 \mathrm{~N}, \beta=0$. The weight of the sprayer boom half is $m=200 \mathrm{~kg}$ and in certain suspension characteristic positions its proportion acting on pendulum elastic-damping element is: $m_{1}=174 \mathrm{~kg} ; m_{2}=182 \mathrm{~kg} ; m_{3}=142 \mathrm{~kg}$. Thus there are static deformations of the pendulum elastic-damping element, respectively: $\Delta_{01}=0,045 \mathrm{~m} ; \Delta_{02}=0,047 \mathrm{~m}$; $\Delta_{03}=0,037 \mathrm{~m}$.

An important stage the oscillatory process investigation according to the developed dynamic model is initial conditions determination. We accept them from the condition of the most critical load occurrence when the maximum operation deformation of the pendulum elastic-damping element is reached: $t_{0}=0$, $(z)_{t=t_{0}}=z_{0}=0,08 \mathrm{~m},(\dot{z})_{t=t_{0}}=\dot{z}_{0}=3,3 \mathrm{~m} / \mathrm{s}$. According to the results of mathematical modeling, the following results are obtained, Figure 3,4 .

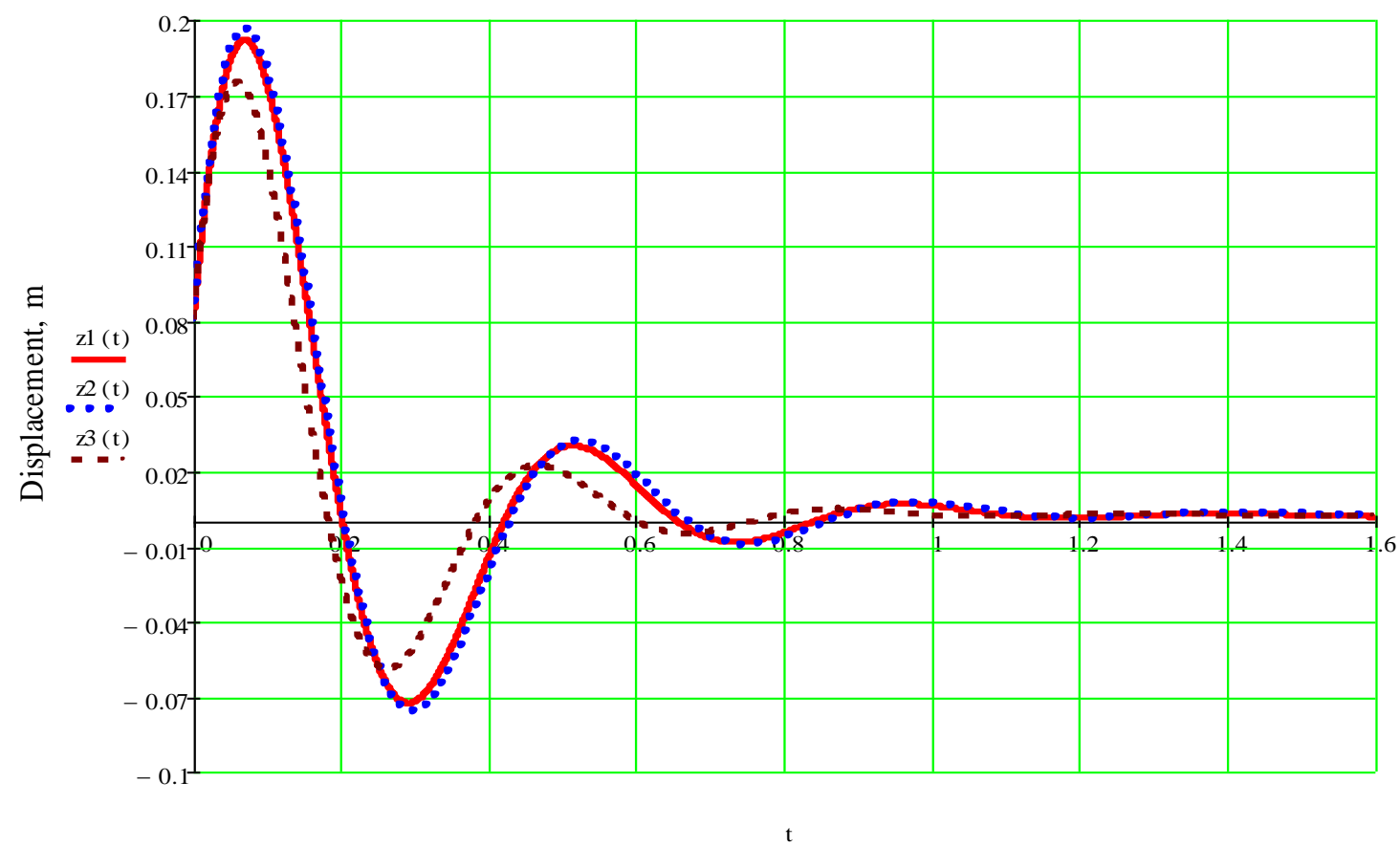

Time, $s$

Figure 3. Graphical dependencies of the law of the reduced mass displacement at point A: $z_{1}(t)-$ solid line corresponding to mass $m_{1}=174 \mathrm{~kg} ; z_{2}(t)-$ the line formed by dots $\left(m_{2}=182 \mathrm{~kg}\right)$;

$$
z_{3}(t) \text { - dotted line }\left(m_{3}=142 \mathrm{~kg}\right)
$$




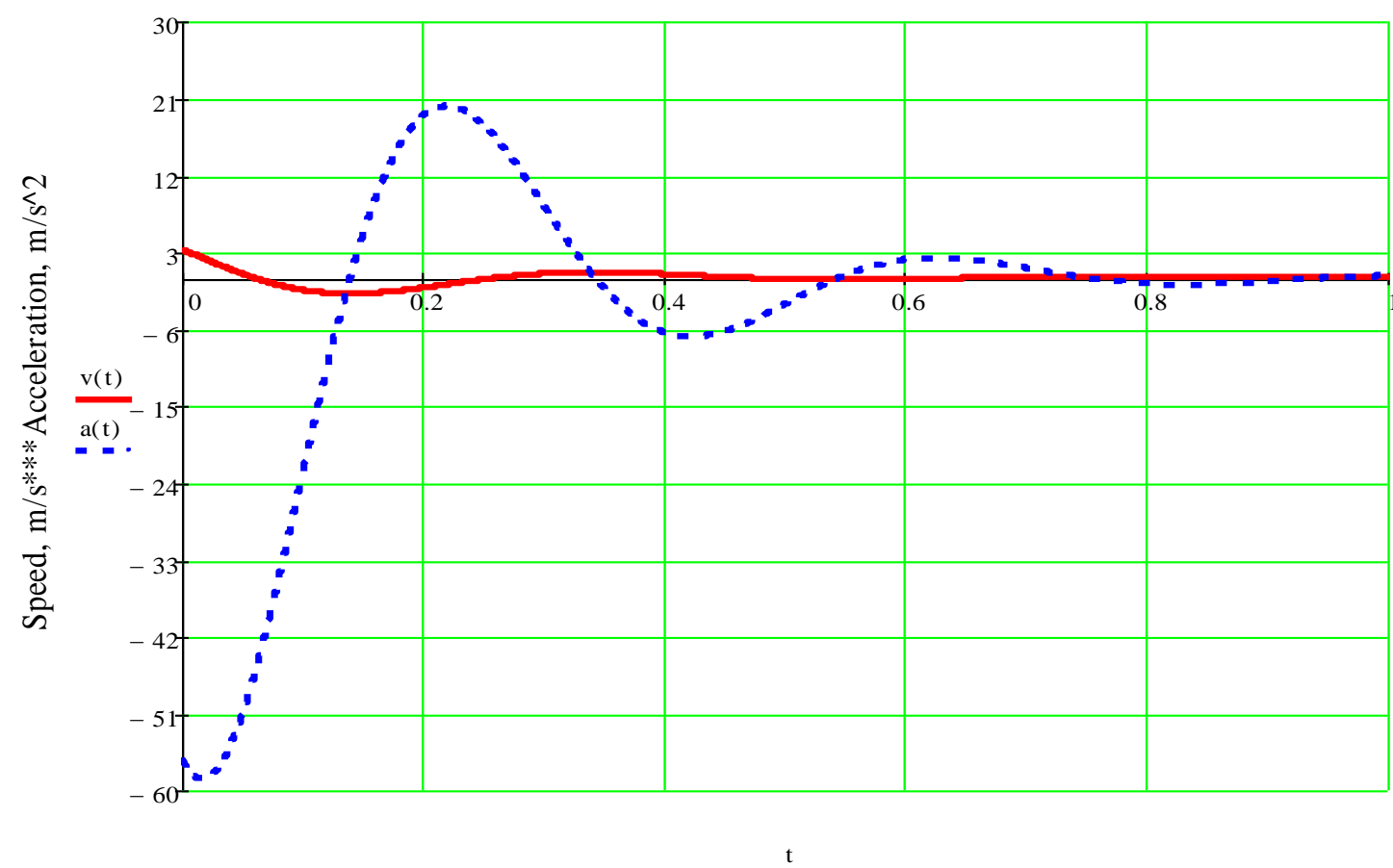

Time, $s$

Figure 4. Graphical dependencies of the reduced speed at point A $v(t)$ (solid line) and acceleration $a(t)$ (dashed line)

Conclusions. Based on the new design of the independent "batwing"-type pendulum suspension, its basic kinematic parameters are described, where the relationship between the actual displacement of the sprayer suspension boom $\lambda(\varphi)$ and deformation of the pendulum elastic-damping element $\Delta(\varphi)$ is established. Under the designed dimensions of the boom suspension and in accordance with Figure 2 the maximum difference of the obtained displacements is $36 \%$. This means that, for example, when the sprayer wheels head-on crash, and maximum permissible load on the suspension by boom weight are applied, the deformation of the pendulum elastic-damping element is maximum, i. e. the boom displacement is less than $36 \%$. Under low loads, their movement is almost the same.

In order to test the ability of such boom suspension design to damp oscillations, the dynamic model of its operation for the partial case of occurring oscillations is constructed. The result of oscillation process mathematical modeling is derivation of the reduced mass motion law for the sprayer boom. Based on the initial conditions of the given reduced mass motion, we obtained graphical dependencies (Figure 3) characterizing this oscillation process. It is evident that with the set parameters of the elastic element rigidity $c=3,8 \cdot 10^{4} \frac{\mathrm{N}}{\mathrm{m}}$, the damper viscous resistance coefficient $\mu=1,5 \cdot 10^{3} \frac{N \cdot s}{m}$, the coercive force frequency $\omega=1,5 \mathrm{~Hz}$ and its amplitude $H_{0}=100 \mathrm{~N}$, the maximum deviation of the reduced mass at point $\mathrm{A}$ from the equilibrium position reaches $0,196 \mathrm{~m}$, and the actual boom displacement $-0,129 \mathrm{~m}$. The difference is $34.2 \%$. Almost complete stabilization of the boom is observed after $1 \mathrm{~s}$ of suspension operation, Figure 3. The constructed dynamic model makes it possible to select parameters of the pendulum elastic-damping elements for real sprayer boom suspension in 
accordance with the existing loads and the given stabilization conditions. Moreover, the dependences of the boom reduced weight velocity and acceleration (Figure 4) on the basis of which it is possible to analyze the nature and value of dynamic loads occurring on the structural elements are obtained.

\section{References}

1. Babii A., Babii M. Impact of oscillation amplitude of boom sprayers load-bearing frame sections. Scientific Journal of TNTU. 2019. Vol. 95. No. 3. P. 97-104. https://doi.org/10.33108/visnyk_tntu2019.03.097

2. Agroexpert. URL: https://agroexpert.ua/obpriskuvanna-na-so-slid-zvernuti-osoblivu-uvagu-0/.

3. Babii A. V. Analiz parametriv shtanhovoho obpryskuvacha z metoyu zbil'shennya yoho produktyvnosti. Machinery \& Energetics. Journal of Rural Production Research. 2019. Vol. 10. No. 4. P. 51-55.

4. Rybak T. I., Babii A. V., Bortnyk I. M. et al. Evaluation of the Service Life of the Frames of Sections of Boom Field Sprayers. Mater Sci 55. 2019. P. 374-380. https://doi.org/10.1007/s11003-019-00312-0

5. Andreikiv O. E., Lysyk A. R., Shtayura N. S. et al. Evaluation of the Residual Service Life of Thin-Walled Structural Elements with Short Corrosion-Fatigue Cracks. Mater Sci 53. 2018. P. 514-521. https://doi.org/10.1007/s11003-018-0104-4

6. Dmytrychenko M. F., Vikovych I. A. Dynamika mobil'nykh mashyn z nachipnymy funktsional'nymy elementamy: Monohrafiya. L'viv: L'vivs'ka politekhnika. 2008. 496 p.

7. Vikovych I. A., Diveyev B. M., Dorosh I. R. Rozrakhunok ta minimizatsiya kolyvnykh protsesiv u shtanhakh obpryskuvachiv. Avtomatyzatsiya vyrobnychykh protsesiv u mashynobuduvanni ta pryladobuduvanni. 2011. Vyp. 45. P. 465-471.

8. Vikovych I. A. Konstruktsiyi i dynamika shtanhovykh obpryskuvachiv: monohrafiya. L'viv: "L'vivs'koyi politekhniky". 2003. $460 \mathrm{p}$.

9. Pidviska shtanhy obpryskuvacha: deklaratsiynyy patent na korysnu model' 11792 A01M 7/00; zayavleno 13.06.2005 u200505794; opublikovano 16.01.2006, Byul. № 1.

10. Tymoshenko S. P., Yanh D. Kh., Uyver U. Kolebanyya v ynzhenernom dele / per. $\mathrm{s}$ anhl. L. H. Korneychuka; pod red. E. Y. Hryholyuka. M.: Mashynostroenye, 1985. 472 p.

\section{Список використаної літератури}

1. Babii A., Babii M. Impact of oscillation amplitude of boom sprayers load-bearing frame sections. Scientific Journal of TNTU. 2019. Vol. 95. No. 3. P. 97-104. https://doi.org/10.33108/visnyk_tntu2019.03.097

2. Agroexpert. URL: https://agroexpert.ua/obpriskuvanna-na-so-slid-zvernuti-osoblivu-uvagu-0/.

3. Бабій А. В. Аналіз параметрів штангового обприскувача з метою збільшення його продуктивності. Machinery \& Energetics. Journal of Rural Production Research. 2019. Vol. 10. No. 4. P. 51-55.

4. Rybak T. I., Babii A. V., Bortnyk I. M. et al. Evaluation of the Service Life of the Frames of Sections of Boom Field Sprayers. Mater Sci 55. 2019. P. 374-380. https://doi.org/10.1007/s11003-019-00312-0

5. Andreikiv O. E., Lysyk A. R., Shtayura N. S. et al. Evaluation of the Residual Service Life of Thin-Walled Structural Elements with Short Corrosion-Fatigue Cracks. Mater Sci 53. 2018. P. 514-521. https://doi.org/10.1007/s11003-018-0104-4

6. Дмитриченко М. Ф., Вікович І. А. Динаміка мобільних машин з начіпними функціональними елементами: монографія. Львів: Львівська політехніка, 2008. 496 с.

7. Вікович І. А., Дівеєв Б. М., Дорош І. Р. Розрахунок та мінімізація коливних процесів у штангах обприскувачів. Автоматизація виробничих процесів у машинобудуванні та приладобудуванні. 2011. Вип. 45. С. 465-471.

8. Вікович І. А. Конструкції і динаміка штангових обприскувачів: монографія. Львів: Львівська політехніка, 2003. 460 c.

9. Підвіска штанги обприскувача: деклараційний патент на корисну модель 11792 А01M 7/00; заявлено 13.06.2005 u200505794; опубліковано 16.01.2006, Бюл. № 1.

10. Тимошенко С. П., Янг Д. Х., Уивер У. Колебания в инженерном деле / пер. с англ. Л. Г. Корнейчука; под ред. Э. И. Григолюка. М.: Машиностроение, 1985. 472 с. 


\title{
УДК 631.348.45:534.1
}

\section{ДОСЛІДЖЕННЯ ПАРАМЕТРІВ НЕЗАЛЕЖНОЇ МАЯТНИКОВОЇ ПІДВІСКИ ШТАНГИ ОБПРИСКУВАЧА}

\author{
Андрій Бабій \\ Тернопільський начіональний технічний університет імені Івана Пулюя, \\ Тернопіль, Україна
}

\begin{abstract}
Резюме. Важко собі уявити виробниџтво сільськогосподарської продукиії рослинництва без виконання технологічної операції хімічного захисту. Це один з найефективніших способів захисту рослин. Він є небезпечним щуодо дії на живий організм та навколишнє середовище. Ефективність хімічного захисту може суттєво знизитися через недотримання норми внесення препарату чи несвоєчасності виконання даної технологічної операції.

Зосереджено увагу на можливому відхиленні норми внесення робочого препарату на поверхні рослин через виникнення коливань навісної итанги. Розроблено нову конструкиію підвіски штанги, яка спроектована у вигляді чотириланкової важільної Ж-подібної підвіски. Ї̈ особливістю є те, щзо вона виконана двома незалежними двоплечовими маятниками, коливання яких обмежується шарнірно приєднаними пружно-демпфуючими елементами. Для дослідження параметрів такої підвіски проведено аналітичне моделювання ї̈ роботи. Встановлено кінематичний взаємозв'язок між деформачією пружного елемента підвіски та переміщенням навісної штанги обприскувача. Характерною відмінністю конструкиії є те, щчо при малих амплітудах коливань итанги деформація пружно-демпфуючих елементів та переміщення штанги практично співпадають, а при амплітудах, близьких до максимальних, пружний елемент має відносно велику деформацію, а фактичне переміщення штанги є меншим на 36\%. Даний ефект сприяє зменшенню амплітуди коливань навісної штанги. Для перевірки здатності даної незалежної підвіски гасити коливання штанги обприскувача розроблено динамічну модель, яка описує ией коливний процес. На прикладі часткового випадку виникаючих коливань итанги отримано розв'язки, за аналізом яких можна оцінити ефективність роботи запропонованої підвіски. Також зроблено відповідні висновки щзодо отриманих результатів і намічено шляхи подальших досліджень.
\end{abstract}

Ключові слова: итанга обприскувача, амплітуда, статичне переміщення, підвіска, маятник, деформація, коливання, стабілізація цттанги.

https://doi.org/10.33108/visnyk_tntu2019.04.090

Отримано 04.01.2020 